\title{
Near-infrared light regulation of tumor PI3K/Akt signaling pathway for enhancing cancer cell apoptosis through conjugated polymer nanoparticles
}

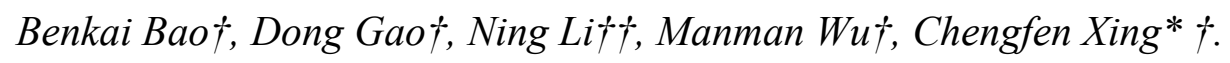

$\dagger$ Key Laboratory of Hebei Province for Molecular Biophysics, Institute of Biophysics, Hebei University of Technology, Tianjin 300400, P.R. China

$\dagger \uparrow$ School of Materials Science and Engineering, Hebei University of Technology Tianjin 300130, P. R. China

Benkai Bao†: benkibio@163.com; Dong Gao $\uparrow:$ gaodong@iccas.ac.cn

Ning Li††: ningzili1121@163.com; Manman Wu†: 643607981@qq.com

Chengfen Xing*†: xingc@hebut.edu.cn 


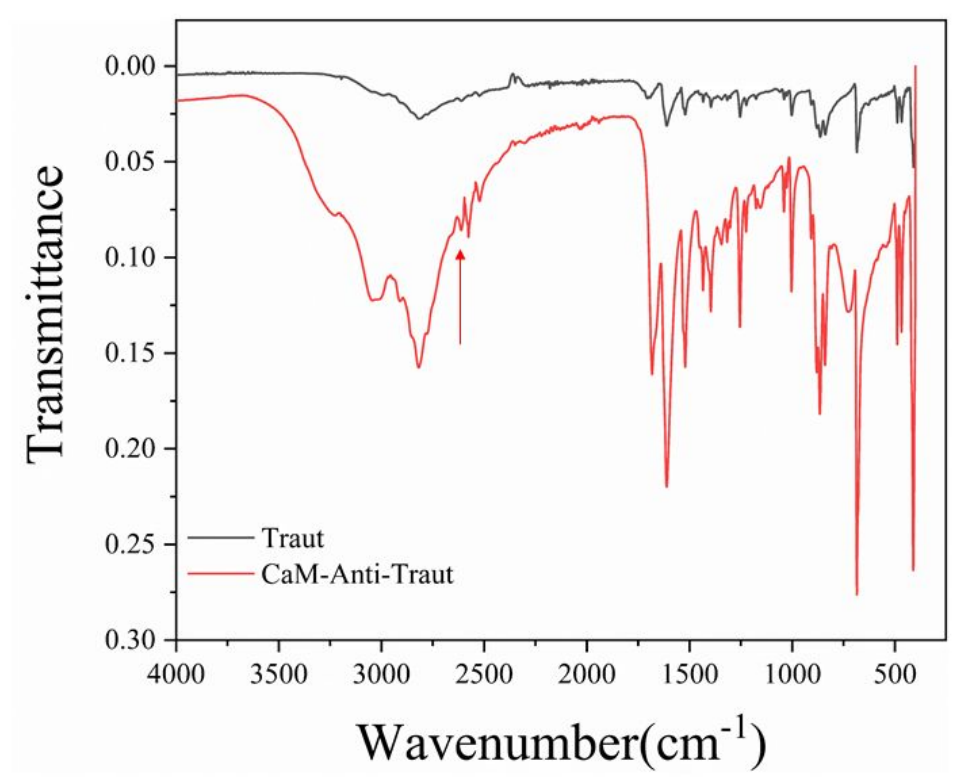

Figure S1. Infrared absorption spectra of Traut's Reagent and CaM-Anti-Traut. The infrared characteristic peak of the mercapto group is at $1550-1560 \mathrm{~nm}$.

\begin{tabular}{cc}
\hline Samples & Zeta potentials $(\zeta, \mathrm{mV})$ \\
\hline CPNs & $-27.8 \pm 1.60$ \\
CPNs-C & $-6.60 \pm 1.59$ \\
\hline
\end{tabular}


Table S1. Zeta potential maps of CPNs and CPNs-C. [CPNs] $=15 \mu \mathrm{g} \mathrm{mL}^{-1}$ [CPNs-C] $=15 \mu \mathrm{g} \mathrm{mL} L^{-1}$.
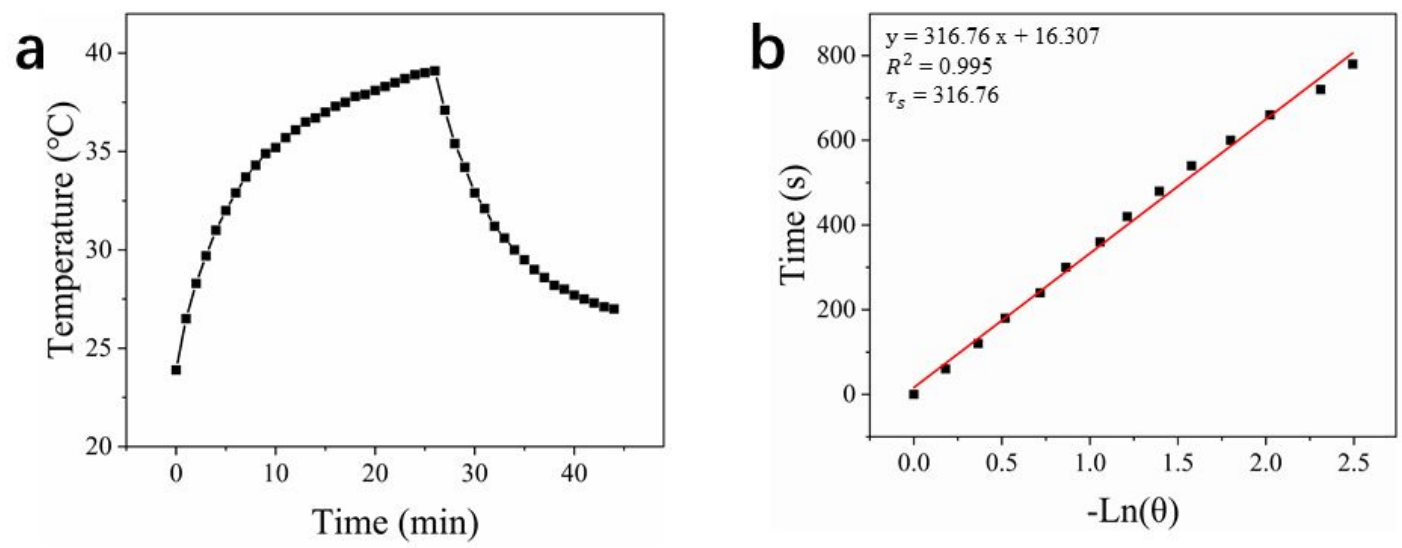

Figure S2. Photothermal conversion efficiency analysis of CPNs. (a) The heating and cooling curve of CPNs. $\mathrm{P}_{808 \mathrm{~nm}}=0.8 \mathrm{~W} / \mathrm{cm}^{2}$. $[\mathrm{CPNs}]=15 \mu \mathrm{g} \mathrm{mL} \mathrm{m}^{-1}$. (b) Determine the time constant of heat transfer from the system as $\tau_{s}$, by applying the linearized energy balance to the temperature and time data in the cooling cycle of the figure a. The slope is $\tau_{s}$. In the equation, " $\mathrm{m}$ " is the mass of the solvent, "c" is the specific heat capacity of the solvent, and " $A_{\lambda}$ " is the absorbance of CPNs at $808 \mathrm{~nm}$.

$$
\eta=\frac{h s\left(T_{\max }-T_{\text {surr }}\right)-Q_{\text {dis }}}{I\left(1-10^{-\left(A_{\lambda}\right)}\right)}=\frac{m c \cdot \tau_{s}\left(T_{\text {max }}-T_{\text {surr }}\right)-Q_{\text {dis }}}{I\left(1-10^{-\left(A_{\lambda}\right)}\right)}
$$



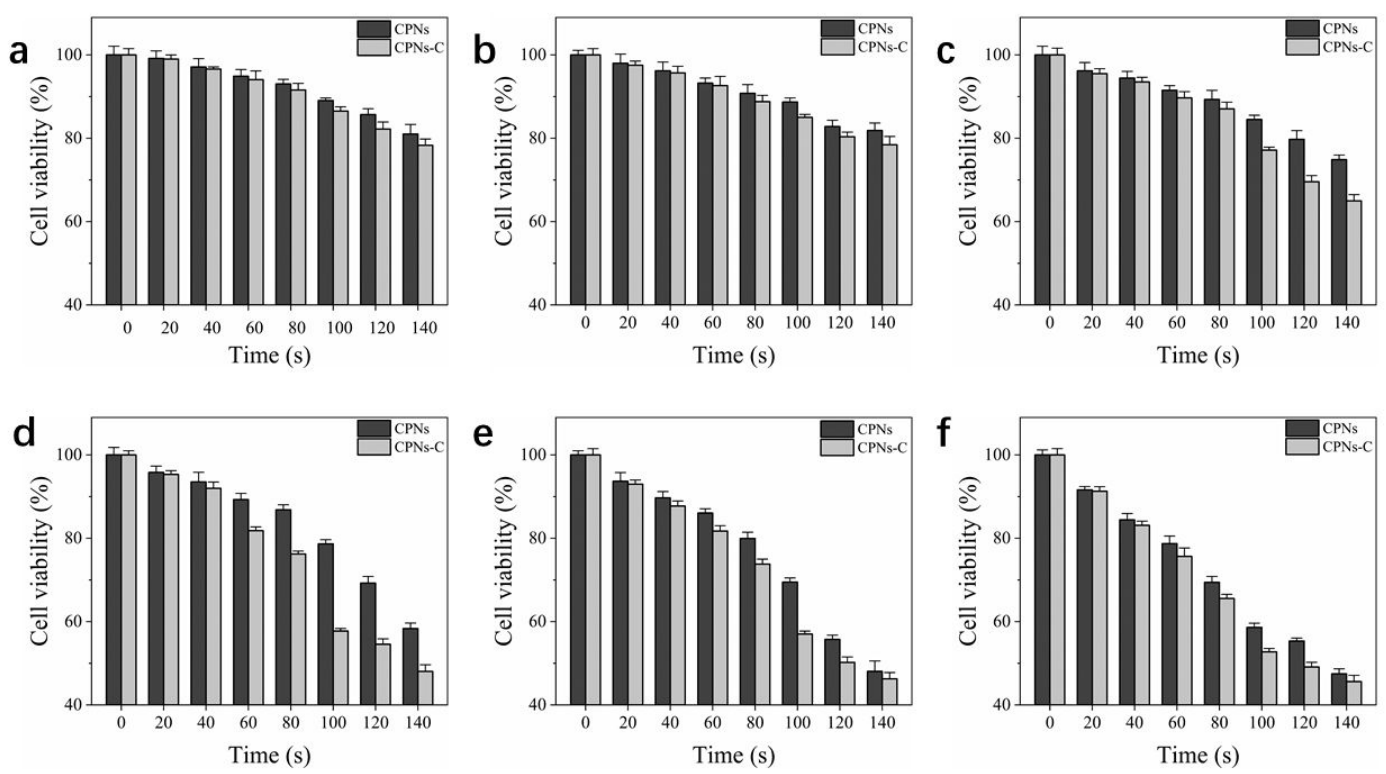

Figure S3. The cell viability of MCF-7 cells after CPNs and CPNs-C were irradiated with $808 \mathrm{~nm}$ laser for different time. [CPNs] $=15 \mu \mathrm{g} \mathrm{mL}^{-1}$ [CPNs-C] $=15 \mu \mathrm{g} \mathrm{mL}^{-1}$. (a) $\mathrm{P}_{808 \mathrm{~nm}}=0.5 \mathrm{~W} / \mathrm{cm}^{2}$. (b) $\mathrm{P}_{808 \mathrm{~nm}}=0.6 \mathrm{~W} / \mathrm{cm}^{2}$. (c) $\mathrm{P}_{808 \mathrm{~nm}}=0.7 \mathrm{~W} / \mathrm{cm}^{2}$. (d) $\mathrm{P}_{808 \mathrm{~nm}}=0.8$ $\mathrm{W} / \mathrm{cm}^{2}$. (e) $\mathrm{P}_{808 \mathrm{~nm}}=0.9 \mathrm{~W} / \mathrm{cm}^{2}$. (f) $\mathrm{P}_{808 \mathrm{~nm}}=1.0 \mathrm{~W} / \mathrm{cm}^{2}$.
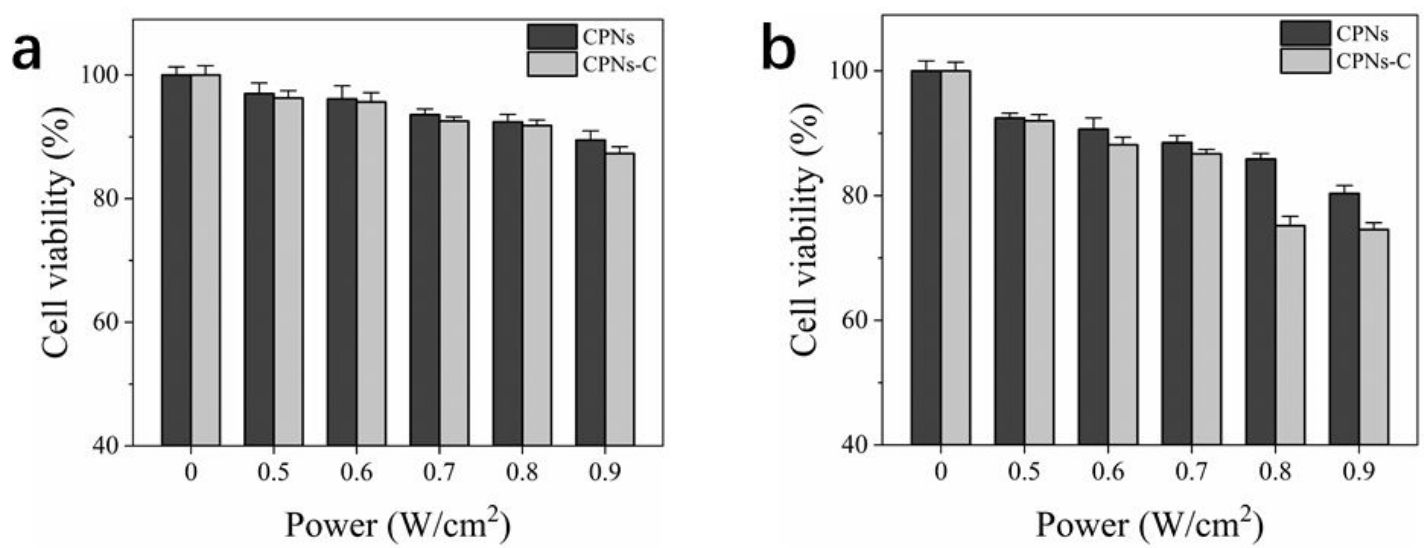

Figure S4. The cell viability of MCF-7 cells after irradiating CPNs and CPNs-C with $808 \mathrm{~nm}$ lasers of different powers. (a) $[\mathrm{CPNs}]=9 \mu \mathrm{g} \mathrm{mL} \mathrm{m}^{-1}[\mathrm{CPNs}-\mathrm{C}]=9 \mu \mathrm{g} \mathrm{mL} \mathrm{m}^{-1}$. (b) $[\mathrm{CPNs}]=12 \mu \mathrm{g} \mathrm{mL}^{-1}[\mathrm{CPNs}-\mathrm{C}]=12 \mu \mathrm{g} \mathrm{mL}^{-1}$. 


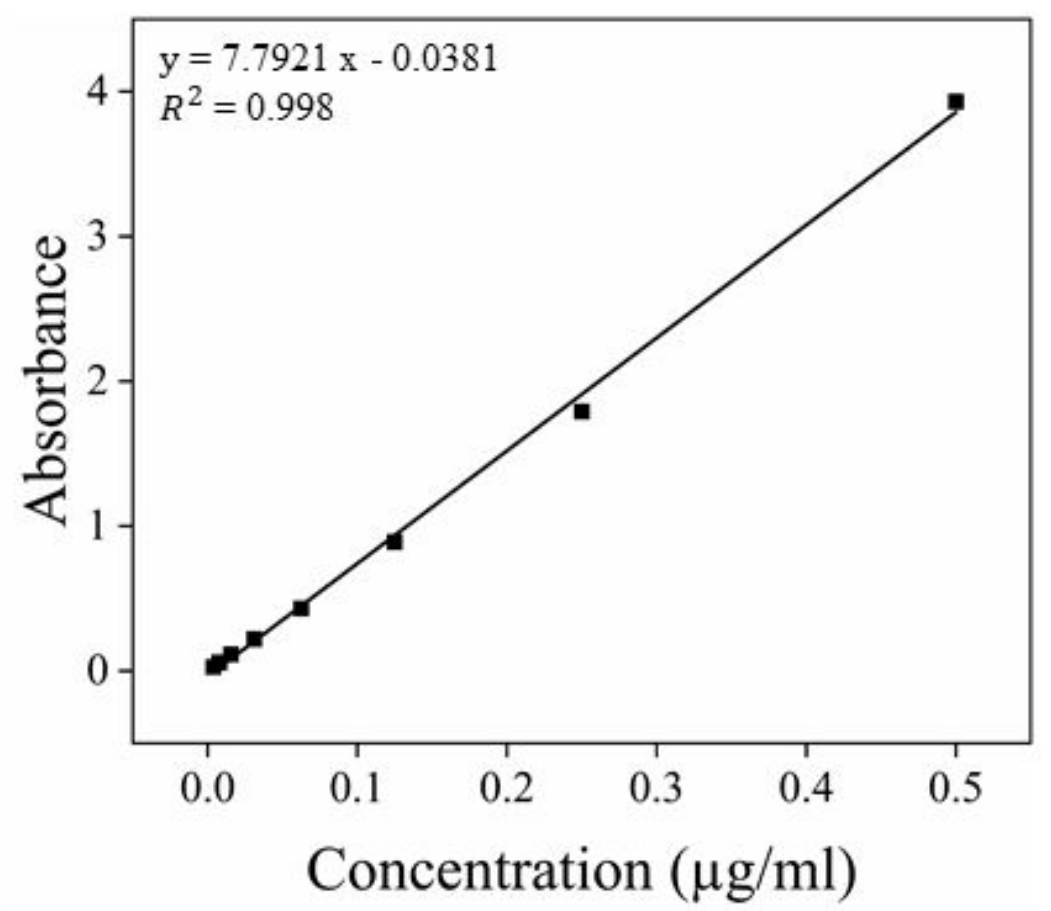

Figure S5. The standard curve of PDPP.

\begin{tabular}{cccc}
\hline & $808 \mathrm{~nm}$ laser & CPNs & CPNs-C \\
\hline 1 & - & - & - \\
2 & + & - & - \\
3 & - & + & - \\
4 & - & - & + \\
5 & + & + & - \\
6 & + & - & + \\
\hline
\end{tabular}

Table S2. MCF-7 cell processing conditions for different groups. "-" Indicates that this condition is not included, and "+" indicates that this condition is included. P808nm = $0.8 \mathrm{~W} / \mathrm{cm}^{2},[\mathrm{CPNs}]=15 \mu \mathrm{g} \mathrm{mL}-1[\mathrm{CPNs}-\mathrm{C}]=15 \mu \mathrm{g} \mathrm{mL}-1$. 


\begin{tabular}{ccccccccc}
\hline number & $\mathbf{1}$ & $\mathbf{2}$ & $\mathbf{3}$ & $\mathbf{4}$ & $\mathbf{5}$ & $\mathbf{6}$ & $\mathbf{7}$ & $\mathbf{8}$ \\
\hline Standard protein $(\mu \mathrm{l})$ & 0 & 3 & 6 & 12 & 24 & 36 & 48 & 60 \\
$\mathrm{H}_{2} \mathrm{O}(\mu \mathrm{l})$ & 60 & 57 & 54 & 48 & 36 & 24 & 12 & 0 \\
$\mathrm{BCA}(\mu \mathrm{l})$ & 600 & 600 & 600 & 600 & 600 & 600 & 600 & 600 \\
concentration $(\mu \mathrm{g} / \mathrm{ml})$ & 0 & 0.025 & 0.05 & 0.1 & 0.2 & 0.3 & 0.4 & 0.5 \\
\hline
\end{tabular}

Table S3. Gradient standard protein concentration table.

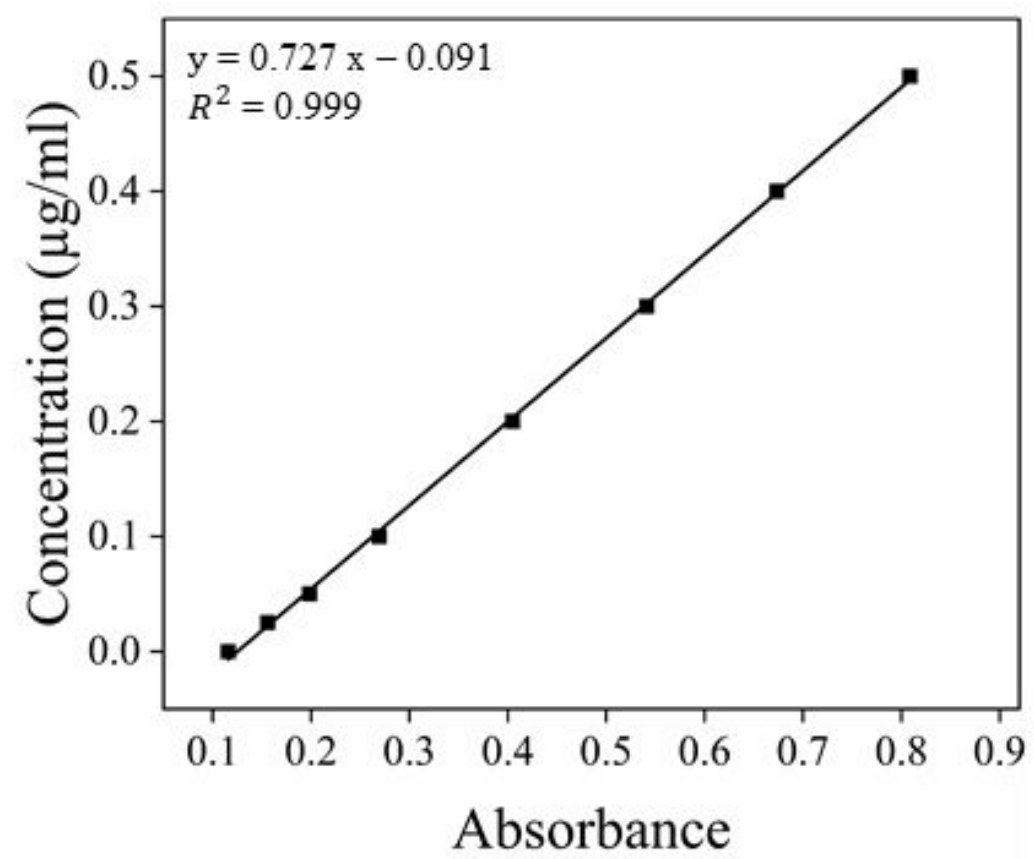

Figure S6. The standard curve of total cell protein. 


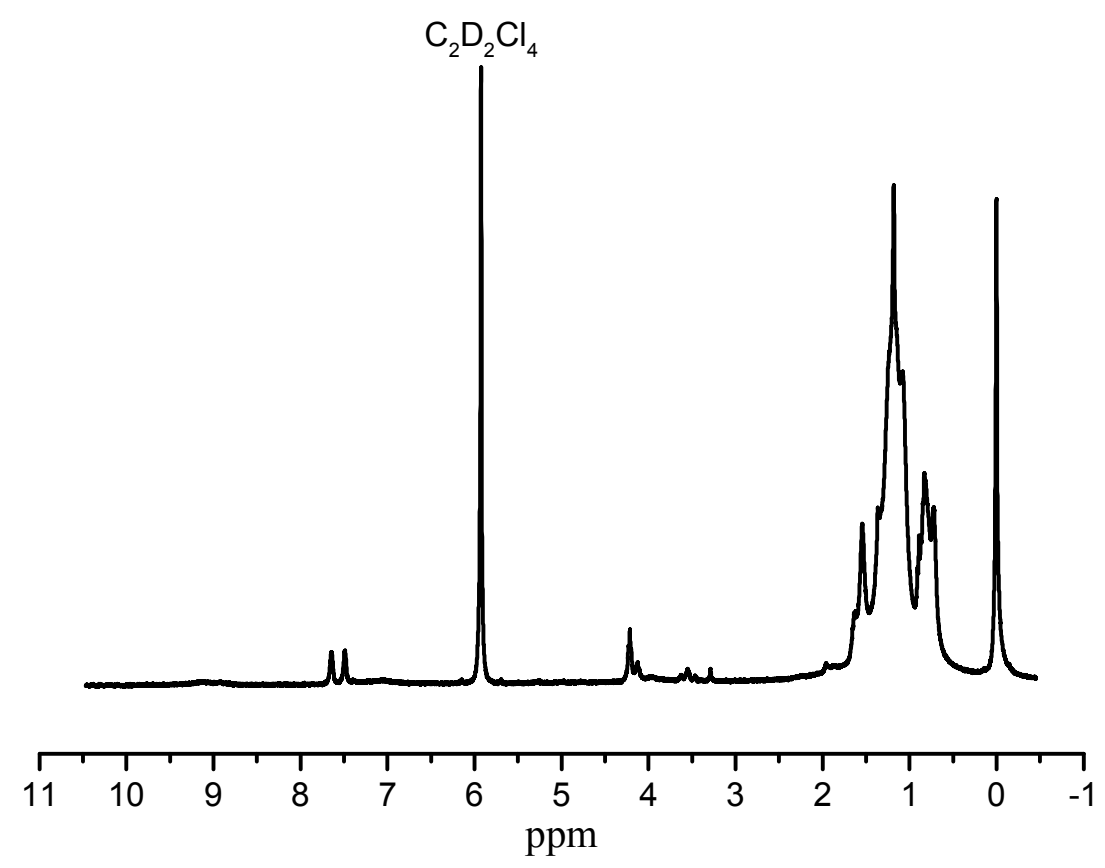

Figure S7. ${ }^{1} \mathrm{H}$ NMR spectrum of PDPP. 